\title{
Effect of Seed Treatment with Fungicide, Micronutrients and Biofertilizers on Growth and Yield of Chickpea in Madhya Pradesh, India
}

\author{
Megha Dubey*, V.K. Verma, Nidhi Verma, Anjum Ahmed and Usha Waskle \\ Krishi Vigyan Kendra, Betul, J. N. K. V. V, Jabalpur, Madhya Pradesh 482 004, India \\ *Corresponding author
}

\begin{tabular}{|l|}
\hline Ke y w o r d s \\
Chickpea, \\
Molybdenum, \\
Boron, Biofertilizer, \\
Thiophanate \\
methyl, \\
Pyroclostrobin \\
\hline Article Info \\
\hline $\begin{array}{l}\text { Accepted: } \\
10 \text { October } 2019 \\
\text { Available Online: } \\
\text { 10 November } 2019\end{array}$ \\
\hline
\end{tabular}

A B S T R A C T
A field experiment was carried out during the Rabi season of the year 2018 to find out the effect of seed treatment with fungicide, micronutrients and biofertilizers on growth and yield attributing characters of chickpea. The micro nutrients like molybdenum and boron were used for seed treatment in chickpea and resulted in increase in germination percent, growth of plants and yield attributing characters were improved. The experiment comprises of 8 treatments with3 replications. The treatment T7 in which seed treatment was done with $2 \mathrm{ml} / \mathrm{kg}$ of fungicide (Thiophanate methyl 45\%+Pyroclostrobin 5\%FS) $2 \mathrm{~g}$ of Boron $+1 \mathrm{~g}$ Moylbdenum $+10 \mathrm{ml}$ from each of Rhizobium, PSB and Tricoderma culture has resulted in increase plant height $(35.17 \mathrm{~cm})$, branches/plant $(10.2)$, number of pods /plant(54.67),100 seed weight $(20.14 \mathrm{~g})$,grain yield $(26.23 \mathrm{q} / \mathrm{hec})$ and straw yield (30.17 q/hec). Micronutrients play an important role in increasing yield of pulses and oilseed legumes through their effects on the plant itself and on the nitrogen fixing symbiotic process. The deficiency of these nutrients has been very pronounced under multiple cropping systems due to excess removal by HYV of crops and hence their exogenous supplies are urgently required. Molybdenum is required for the formation of the nitrate reductase enzyme and in the legume it plays an additional role in symbiotic nitrogen fixation. The nitrogen fixing enzyme, nitrogenase is composed of molybdenum and iron and without adequate quantities of these elements, nitrogen fixation can't occur. Boron is very important in cell division and in pod and seed formation. Boron ranks third place among micronutrients in its concentration in seed and stem as well as its total amount after zinc. The critical level of boron with reference to crops in general was reported to be 0.15 to $0.20 \mathrm{ppm}$ depending on soil type. Fusarium wilt caused by Fusarium oxysporum $f$. sp. ciceris (Foc) is the most serious and widespread disease of chickpea, causing a $100 \%$ loss under favorable conditions. The treatment improved the gross income by 97235.60 and net income by 68280.10 with benefit cost ration of 2.3 .

\section{Introduction}

Madhya Pradesh has contributed a significant $34 \%$ of the total gram area and $41 \%$ of total gram production in the country, thereby ranking first both in area and production. Maharashtra (18\%) and Rajasthan (13\%) were the next in terms of area. More than 90 per cent of gram production of the country during the period under report has been realized by 
10 states of MP, MS, Rajasthan, Karnataka, UP, AP, Gujarat, Jharkhand, CG and Telangana (Annual report 2017-18). The overall productivity of chickpea in India is comparatively low due to various biotic and abiotic stress. This include micro nutrient deficiencies in the soil, improper doses of seed treatment, no use of cultures and fungicides has reduced the germination and growth of chickpea during early stage of growth. Therefore, the plant growth during initial stages in restricted and plant stand is not established. Boron and molybdenum are the two important micronutrients which are necessary for chickpea plant growth. Due to continuous use of chemical fertilizer like DAP and MOP the micro nutrients are getting depleted from the soils. Therefore, these nutrients will give better response when they are applied as seed treatment in chickpea. Inorganic fertilizer alone cannot sustain the soil productivity as well as the large scale use of only chemical fertilizers as a source of nutrients has less efficient (Kumar et al., 2003).

Fungicides were able to increase plant emergence from symptomatic seeds when compared with a control in the growth chamber trials. In recent years bio fertilizers, viz. Rhizobium and P.S.B. that are ecofriendly and low cost inputs, have emerged as an important and integral component of integrated plant nutrient supply system for pulse crop production. In India, it is grown on marginal soil and the good soil is used for growing other more favor crops. Chickpea productivity is influenced by many factors including sowing time, Rhizobium inoculation, phosphorus solubilizing bacteria, Tricoderma culture, plant population, moisture stress, seed priming etc. For obtaining high grain yield proper management of crop is a must and proper nutrient. Biofertilizer are recognized as an important component of sustainable agriculture. Rhizobium culture and phosphorus solubilizing bacteria (PSB) can be used to inoculate pulse crops for enhancing the crop productivity and profitability (Bajracharya and Rai, 2009). Nitrogen is an essential component of several amino acids, enzymes nucleic acids etc is required in comparatively less amount due to biological fixation by pulses. Rhizobia are agriculturally important soil bacteria capable of forming root nodules and in some cases, stem nodules on leguminous plant, where they can fix atmospheric nitrogen. Hence, the present investigation was conducted to study the effect of different combination of Fungicide, biofertilizers and micro nutrient fertilizers on growth and productivity of chickpea.

\section{Materials and Methods}

The field experiment was conducted at Krishi Vigyan Kendra, Betul Bazar, Betul during Rabi season. The experimental plot was $21^{\circ} 88^{\prime}$ $\mathrm{N}, 77^{\circ} 98^{\prime} \mathrm{E}$ situated near the highway road. The soil of experimental field was sandy clay loam in texture and initial soil sample had 7.2 $\mathrm{pH}, 0.3 \%$ organic carbon, $110 \mathrm{~kg}$ available nitrogen, $12.5 \mathrm{~kg}$ available phosphorus, 134 $\mathrm{kg}$ available potassium and $0.2 \mathrm{~kg}$ available $\mathrm{Zn} \mathrm{ha}{ }^{-1}$. The experiment was laid out in Randomized Block Design with three replication and consisted nine treatments viz. T1-Seed treatment with $2 \mathrm{ml} / \mathrm{kg}$ (Thiophanate methyl 45\% + Pyroclostrobin 5\% FS), T2 Seed treatment with $2 \mathrm{ml} / \mathrm{kg}$ (Thiophanate methyl 45\%+Pyroclostrobin 5\%FS) $+10 \mathrm{ml}$ each of Jawahar Rhizobium, Jawahar PSB and Jawahar Tricoderma culture per kg seed, T3Seed treatment with $2 \mathrm{ml} / \mathrm{kg}$ (Thiophanate methyl 45\%+Pyroclostrobin 5\%FS) $+10 \mathrm{ml}$ Jawahar Rhizobium, Jawahar PSB and Jawahar Tricoderma culture per $\mathrm{kg}$ seed +0.5 g Boron, T4- Seed treatment with $2 \mathrm{ml} / \mathrm{kg}$ (Thiophanate methyl 45\%+Pyroclostrobin $5 \% \mathrm{FS})+10 \mathrm{ml}$ each of Jawahar Rhizobium, Jawahar PSB and Jawahar Tricoderma culture per kg seed $+1 \mathrm{~g}$ Boron, T5- Seed treatment 
with $2 \mathrm{ml} / \mathrm{kg}$ (Thiophanate methyl $45 \%+$ Pyroclostrobin $5 \%$ FS) $+10 \mathrm{ml}$ each of Jawahar Rhizobium, Jawahar PSB and Jawahar Tricoderma culture per $\mathrm{kg}$ seed +1.5 g Boron, T6- Seed treatment with $2 \mathrm{ml} / \mathrm{kg}$ (Thiophanate methyl 45\%+Pyroclostrobin $5 \%$ FS) $+10 \mathrm{ml}$ each of Jawahar Rhizobium, Jawahar PSB and Jawahar Tricoderma culture per $\mathrm{kg}$ seed $+2 \mathrm{~g}$ Boron,T7 - Seed treatment with $2 \mathrm{ml} / \mathrm{kg}$ (Thiophanate methyl 45\%+ Pyroclostrobin 5\%FS) $+10 \mathrm{ml}$ each of Jawahar Rhizobium, Jawahar PSB and Jawahar Tricoderma culture per $\mathrm{kg}$ seed $+2 \mathrm{~g}$ Boron $+0.5 \mathrm{~g}$ Molybdenum,T8 - Seed treatment with $2 \mathrm{ml} / \mathrm{kg}$ (Thiophanate methyl $45 \%+$ Pyroclostrobin 5\%FS) $+10 \mathrm{ml}$ each of Jawahar Rhizobium, Jawahar PSB and Jawahar Tricoderma culture per $\mathrm{kg}$ seed $+2 \mathrm{~g}$ Boron +1 g Molybdenum, T9 - Without seed treatment. Chickpea variety JG12 was sown $70 \mathrm{~kg} \mathrm{ha}^{-1}$ seed at row spacing of $45 \mathrm{~cm}$ apart with seed drill on $12^{\text {th }}$ October, 2018. The size of the experimental plot was $5 \mathrm{~m}$ x $4 \mathrm{~m}$. The statistical analysis of data was carried out by "Analysis of Variance" method (Panse and Sukhatme, 1967).

\section{Results and Discussion}

\section{Effect on growth attributing characters}

Differences in growth and yield attributes differed significantly due to different combination of fungicide, biofertilizers and micro nutrient slike boron and molybdenum on growth of chickpea. The data from Table 1 revealed that treatment $\mathrm{T} 7$ (seed treatment with fungicide @ $2 \mathrm{ml} / \mathrm{kg}$ of seed (Thiophanate methyl 45\%+Pyroclostrobin $5 \%$ FS) $+10 \mathrm{ml}$ each of Jawahar Rhizobium, Jawahar PSB and Jawahar Tricoderma culture per $\mathrm{kg}$ of seed $+2 \mathrm{~g}$ Boron $+0.5 \mathrm{~g}$ Molybdenum) has produced significantly higher plant height $(35.17 \mathrm{~cm})$, number of branches plant ${ }^{-1}(10.2)$, number of pod plant ${ }^{-1}$ (54.67), 100 seed weight (20.14 g), grain yield (26.23 q/hec) and straw yield (30.17 q/hec) over rest of the treatments except treatment T8 (Seed treatment with $2 \mathrm{ml} / \mathrm{kg}$ (Thiophanate methyl $45 \%+$ Pyroclostrobin 5\%FS)+10 ml Rhizobium, PSB and Tricoderma culture per $\mathrm{kg}$ seed $+2 \mathrm{~g}$ Boron $+1 \mathrm{~g}$ Molybdenum) and T6 (Seed treatment with $2 \mathrm{ml} / \mathrm{kg}$ of seed (Thiophanate methyl 45\%+Pyroclostrobin $5 \% \mathrm{FS})+10 \mathrm{ml}$ each of Jawahar Rhizobium, Jawahar PSB and Jawahar Tricoderma culture per $\mathrm{kg}$ seed $+2 \mathrm{~g}$ Boron)which having at par each others. The minimum values of all growth and yield attributes were significantly recorded on T9 (Without seed treatment). The higher values of yields with treatment T7 (seed treatment with fungicide @ $2 \mathrm{ml} / \mathrm{kg}$ of seed (Thiophanate methyl 45\%+ Pyroclostrobin 5\%FS) $+10 \mathrm{ml}$ each of Jawahar Rhizobium, Jawahar PSB and Jawahar Tricoderma culture per $\mathrm{kg}$ of seed $+2 \mathrm{~g}$ Boron +0.5 g Molybdenum) $26.23 \mathrm{q} /$ hec followed by application of T8 (seed treatment with fungicide@ $2 \mathrm{ml} / \mathrm{kg}$ of seed (Thiophanate methyl 45\% + Pyroclostrobin 5\%FS) +10 ml each of Jawahar Rhizobium, Jawahar PSB and Jawahar Tricoderma culture per $\mathrm{kg}$ of seed +2 g Boron $+1 \mathrm{~g}$ Molybdenum $25.21 \mathrm{q} / \mathrm{hec}$ and T6 (seed treatment with fungicide @ 2 ml $/ \mathrm{kg}$ of seed (Thiophanate methyl 45\%+ Pyroclostrobin 5\%FS) $+10 \mathrm{ml}$ each of Jawahar Rhizobium, Jawahar PSB and Jawahar Tricoderma culture per $\mathrm{kg}$ of seed $+2 \mathrm{~g}$ Boron resulted in $24.13 \mathrm{q} / \mathrm{hec}$ yield. Due to proper doses of fungicide and inoculation of Jawahar Rhizobium, Jawahar PSB and Jawahar Tricoderma which has increased growth of chickpea, reduced the infestation of fungal diseases and yield attributing characters (mean plant height, branches plant ${ }^{-1}$, pod plant ${ }^{-1}, 100$ grain weight grain and straw yield) by enhancing availability of nutrients from the soil by means of culture media, provided protection against fungal diseases and application of micronutrients like boron and molybdenum has resulted in healthy growth of plants, thereby given positive impact on growth and productivity of chickpea. 
Table.1 Mean plant height, branches plant ${ }^{-1}$, number of pods plant ${ }^{-1}, 100$ seed weight, grain yield, straw yield as influenced by different treatments

\begin{tabular}{|c|c|c|c|c|c|c|}
\hline Treatment & $\begin{array}{l}\text { Plant } \\
\text { height } \\
(\mathbf{c m})\end{array}$ & $\begin{array}{l}\text { Branches } \\
\text { plant }^{-1}\end{array}$ & $\begin{array}{l}\text { No of } \\
\text { pods } \\
\text { plant }^{-1}\end{array}$ & $\begin{array}{l}100 \text { seed } \\
\text { weight }(g)\end{array}$ & $\begin{array}{l}\text { Grain } \\
\text { yield } \\
\text { (q/hec) }\end{array}$ & $\begin{array}{l}\text { Straw yield } \\
\quad(\mathbf{q} / \mathrm{hec})\end{array}$ \\
\hline $\begin{array}{l}\text { T1-Seed treatment with }+2 \mathrm{ml} / \mathrm{kg} \text { (Thiophanate methyl } \\
45 \%+\text { Pyroclostrobin } 5 \% \mathrm{FS} \text { ) }\end{array}$ & 27.48 & 6.5 & 34.18 & 15.19 & 15.12 & 17.23 \\
\hline $\begin{array}{l}\text { T2-Seed treatment with } 2 \mathrm{ml} / \mathrm{kg} \text { (Thiophanate methyl } \\
45 \%+\text { Pyroclostrobin } 5 \% \mathrm{FS} \text { ) }+10 \mathrm{ml} \text { Rhizobium, PSB and } \\
\text { Tricoderma culture per } \mathrm{kg} \text { seed }\end{array}$ & 29.50 & 6.8 & 40.14 & 16.34 & 17.35 & 19.24 \\
\hline $\begin{array}{l}\text { T3-Seed treatment with } 2 \mathrm{ml} / \mathrm{kg} \text { (Thiophanate methyl } \\
45 \%+\text { Pyroclostrobin } 5 \% \mathrm{FS} \text { ) }+10 \mathrm{ml} \text { Rhizobium, PSB and } \\
\text { Tricoderma culture per } \mathrm{kg} \text { seed }+0.5 \mathrm{~g} \text { Boron }\end{array}$ & 31.14 & 7.7 & 43.11 & 17.84 & 19.9 & 20.27 \\
\hline $\begin{array}{l}\text { T4-Seed treatment with } 2 \mathrm{ml} / \mathrm{kg} \text { (Thiophanate methyl } \\
45 \%+\text { Pyroclostrobin } 5 \% \mathrm{FS} \text { ) }+10 \mathrm{ml} \text { Rhizobium, PSB and } \\
\text { Tricoderma culture per } \mathrm{kg} \text { seed }+1 \mathrm{~g} \text { Boron }\end{array}$ & 32.14 & 8.5 & 46.91 & 18.23 & 20.17 & 22.12 \\
\hline $\begin{array}{l}\text { T5-Seed treatment with } 2 \mathrm{ml} / \mathrm{kg} \text { (Thiophanate methyl } \\
45 \%+\text { Pyroclostrobin } 5 \% \mathrm{FS} \text { ) }+10 \mathrm{ml} \text { Rhizobium, PSB and } \\
\text { Tricoderma culture per } \mathrm{kg} \text { seed }+1.5 \mathrm{~g} \text { Boron }\end{array}$ & 33.14 & 9.1 & 47.18 & 18.56 & 22.39 & 24.16 \\
\hline $\begin{array}{l}\text { T6-Seed treatment with } 2 \mathrm{ml} / \mathrm{kg} \text { (Thiophanate methyl } \\
45 \%+\text { Pyroclostrobin } 5 \% \mathrm{FS} \text { ) }+10 \mathrm{ml} \text { Rhizobium, PSB and } \\
\text { Tricoderma culture per } \mathrm{kg} \text { seed }+2 \mathrm{~g} \text { Boron }\end{array}$ & 34.12 & 9.6 & 50.12 & 19.14 & 24.13 & 28.41 \\
\hline $\begin{array}{l}\text { T7-Seed treatment with } 2 \mathrm{ml} / \mathrm{kg} \text { (Thiophanate methyl } \\
45 \%+\text { Pyroclostrobin } 5 \% \mathrm{FS})+10 \mathrm{ml} \text { Rhizobium, PSB and } \\
\text { Tricoderma culture per } \mathrm{kg} \text { seed }+2 \mathrm{~g} \text { Boron }+0.5 \mathrm{~g} \\
\text { Molybdenum }\end{array}$ & 35.17 & 10.2 & 54.67 & 20.14 & 26.23 & 30.17 \\
\hline $\begin{array}{l}\text { T8-Seed treatment with } 2 \mathrm{ml} / \mathrm{kg} \text { (Thiophanate methyl } \\
45 \%+\text { Pyroclostrobin } 5 \% \mathrm{FS})+10 \mathrm{ml} \text { Rhizobium, PSB and } \\
\text { Tricoderma culture per } \mathrm{kg} \text { seed }+2 \mathrm{~g} \text { Boron }+1 \mathrm{~g} \\
\text { Molybdenum }\end{array}$ & 34.14 & 9.8 & 52.10 & 19.82 & 25.21 & 29.45 \\
\hline T9-Without seed treatment & 28.11 & 6.0 & 29.24 & 14.12 & 13.12 & 19.10 \\
\hline SEm & 0.02 & 0.06 & 0.01 & 0.01 & 0.02 & 0.11 \\
\hline CD & 0.06 & 0.17 & 0.03 & 0.03 & 0.06 & 0.33 \\
\hline
\end{tabular}


Table.2 Mean cost of cultivation, gross and net monetary returns and benefit cost ratio of plant as influenced by different treatments

\begin{tabular}{|c|c|c|c|c|}
\hline Treatment & $\begin{array}{l}\text { Cost of } \\
\text { cultivation } \\
\text { (Rs/hec) }\end{array}$ & $\begin{array}{l}\text { Gross } \\
\text { monetary } \\
\text { return } \\
(\text { Rs/hec) }\end{array}$ & $\begin{array}{l}\text { Net } \\
\text { monetary } \\
\text { return } \\
(\text { Rs/hec) }\end{array}$ & $\begin{array}{l}\text { Benefit } \\
\text { :Cost } \\
\text { ratio }\end{array}$ \\
\hline T1-Seed treatment with $+2 \mathrm{ml} / \mathrm{kg}$ (Thiophanate methyl $45 \%+$ Pyroclostrobin $5 \% \mathrm{FS}$ & 28052.00 & 56021.40 & 27969.40 & 0.9 \\
\hline $\begin{array}{l}\text { T2-Seed treatment with } 2 \mathrm{ml} / \mathrm{kg} \text { (Thiophanate methyl } 45 \%+\text { Pyroclostrobin } 5 \% \mathrm{FS} \text { ) } \\
+10 \mathrm{ml} \text { Rhizobium, PSB and Tricoderma culture per kg seed }\end{array}$ & 28906.00 & 64188.20 & 35282.20 & 1.2 \\
\hline $\begin{array}{l}\text { T3-Seed treatment with } 2 \mathrm{ml} / \mathrm{kg} \text { (Thiophanate methyl } 45 \%+\text { Pyroclostrobin } 5 \% \mathrm{FS} \text { ) } \\
+10 \mathrm{ml} \text { Rhizobium, PSB and Tricoderma culture per } \mathrm{kg} \text { seed }+0.5 \mathrm{~g} \text { Boron }\end{array}$ & 29046.00 & 73298.60 & 44252.60 & 1.5 \\
\hline $\begin{array}{l}\text { T4-Seed treatment with } 2 \mathrm{ml} / \mathrm{kg} \text { (Thiophanate methyl } 45 \%+\text { Pyroclostrobin } 5 \% \mathrm{FS} \text { ) } \\
+10 \mathrm{ml} \text { Rhizobium, PSB and Tricoderma culture per kg seed }+1 \mathrm{~g} \text { Boron }\end{array}$ & 29186.00 & 74576.60 & 45390.60 & 1.5 \\
\hline $\begin{array}{l}\text { T5-Seed treatment with } 2 \mathrm{ml} / \mathrm{kg} \text { (Thiophanate methyl } 45 \%+\text { Pyroclostrobin } 5 \% \mathrm{FS} \\
\text { )+10 } \mathrm{ml} \text { Rhizobium, PSB and Tricoderma culture per } \mathrm{kg} \text { seed }+1.5 \mathrm{~g} \text { Boron }\end{array}$ & 29326.00 & 82713.80 & 53387.80 & 1.8 \\
\hline $\begin{array}{l}\text { T6-Seed treatment with } 2 \mathrm{ml} / \mathrm{kg} \text { (Thiophanate methyl } 45 \%+\text { Pyroclostrobin } 5 \% \mathrm{FS} \text { ) } \\
+10 \mathrm{ml} \text { Rhizobium, PSB and Tricoderma culture per } \mathrm{kg} \text { seed }+2 \mathrm{~g} \text { Boron }\end{array}$ & 28956.00 & 89568.80 & 60612.80 & 2.1 \\
\hline $\begin{array}{l}\text { T7-Seed treatment with } 2 \mathrm{ml} / \mathrm{kg} \text { (Thiophanate methyl } 45 \%+\text { Pyroclostrobin } 5 \% \mathrm{FS} \text { ) } \\
+10 \mathrm{ml} \text { Rhizobium, PSB and Tricoderma culture per } \mathrm{kg} \text { seed }+2 \mathrm{~g} \text { Boron }+0.5 \mathrm{~g} \\
\text { Molybdenum }\end{array}$ & 28955.50 & 97235.60 & 68280.10 & 2.3 \\
\hline $\begin{array}{l}\text { T8-Seed treatment with } 2 \mathrm{ml} / \mathrm{kg} \text { (Thiophanate methyl } 45 \%+\text { Pyroclostrobin } 5 \% \mathrm{FS} \text { )+ } \\
10 \mathrm{ml} \text { Rhizobium, PSB and Tricoderma culture per } \mathrm{kg} \text { seed }+2 \mathrm{~g} \text { Boron }+1 \mathrm{~g} \\
\text { Molybdenum }\end{array}$ & 29005.00 & 93536.00 & 64531.00 & 2.2 \\
\hline T9-Without seed treatment & 27500.00 & 49358.00 & 21858.00 & 0.7 \\
\hline SEm \pm & 0.55 & 0.29 & 0.22 & 0.06 \\
\hline CD (0.05) & 1.59 & 0.85 & 0.64 & 0.16 \\
\hline
\end{tabular}


It has been observed that Jawahar Rhizobium, Jawahar PSB and Jawahar Tricoderma culture has given beneficial effect on growth and yield attributing characters of chickpea. Kumar et al., (2018) reported that application of RDF +3 ton /ha vermicompost+ Rhizobium+PSB +Tricoderma culture has reported plant height $(34.92 \mathrm{~cm})$,number of pods per plant (53.59), weight of 100 grains (19.52 g), grain yield (26.01 q), straw yield (31.51 q), gross monetary return (117060.00), net monetary return (84172.11)and benefit cost ratio 2.56 respectively). Fungicides were found to be absorbed and translocated in seedlings persisting up to 12 days and protect the seedling in a field for 30 days or more evens through roots (Verma, 1976). The chickpea plants treated with fungicides gave 6-14\% disease incidence of Fusarium wilt as compared to untreated plot, which have $80 \%$ incidence.

Similarly, the application of fungicides (except Score) brought tremendous increment in plant growth as well as grain yield. The study revealed that the fungicide applications in chickpea plants were very effective, they have not suppressed the pathogen activities, but also increased the plant growth and grain yield (almost double than the control plants).

Carbendazim seed treatment gave minimum disease incidence of Fusarium wilt and maximum grain yield (Kamdi et al., 2012). Similarly, that fungicide application significantly increased the plant growth and yield, and also decreased Fusarium wilt incidence in chickpea plants. Similar findings were reported by Asewar et al., (2003), Singh and Yadav (2004).

\section{Effect on economics}

The data from Table 2 revealed that application of T7 (seed treatment with fungicide @ $2 \mathrm{ml} / \mathrm{kg}$ of seed (Thiophanate methyl 45\%+Pyroclostrobin 5\%FS) $+10 \mathrm{ml}$ each of Jawahar Rhizobium, Jawahar PSB and Jawahar Tricoderma culture per $\mathrm{kg}$ of seed + $1.5 \mathrm{~g}$ Boron)recorded maximum cost of cultivation (Rs. $29326.0 \mathrm{ha}^{-1}$ ). The treatment T7 resulted in maximum gross monetary return of (Rs 97235.60), net return of Rs (68280.10) with benefit cost ratio of (2.3) which was superior to all other treatments except T8 with gross monetary return of (Rs 93536.00), net return of Rs (64531.00) with benefit cost ratio of (2.2) and T6 with gross monetary return of (Rs 89568.8), net return of Rs (60612.80) with benefit cost ratio of (2.1)

The experiment proved that application of fungicide along with biofertilizers and micro nutrients in the $\mathrm{T} 7$ (Seed treatment with 2 $\mathrm{ml} / \mathrm{kg}$ (Thiophanate methyl $45 \%+$ Pyroclostrobin 5\%FS) $+10 \mathrm{ml}$ Rhizobium, PSB and Tricoderma culture per $\mathrm{kg}$ seed $+2 \mathrm{~g}$ Boron $+0.5 \mathrm{~g}$ Molybdenum) has resulted in highest number of branches per plant (10.2), pods per plant (54.67), 100 grain weight (20.14 g), grain yield (26.23 q/hec), straw yield (30.17 q/hec), cost of cultivation (Rs 28955.50), gross monetary returns (Rs 97235.60), net monetary returns (Rs 68280.10) and benefit cost ratio of 2.3.This treatment was best without any toxic effect and proved superior over all other treatments.

\section{References}

Annual Report (2017-18). Directorate of Pulse Development.

Asewar, B. V., S. S. Bainade, O. D. Kohire and P. S. Bainade (2003). Integrated use of vermicompost and inorganic fertilizer in chickpea. Annals of Plant Physio., 17(2) : 205- 206.

Bajracharya, S. K. and S. K. Rai (2009). Study on the effect of vermicompost on the nodulation and the yield of chickpea. Nepal Agriculture Res. Journal, 9: 132-138. 
Kumar Hemant, Ripudaman Singh, DD Yadav, M Saquib, VP Chahal, Ruchi Yadav and Omkar Singh Yadav (2018). Effect of integrated nutrient management (INM) on productivity and profitability of chickpea (Cicer arietinum L.). International Journal of Chemical Studies : 6(6): 1672-1674

Kumar S, Singh RC, Kadian VS. (2003) Performance of Mungbean as Influenced by Seed Inoculation with Rhizobium and Levels of Organic and Inorganic Sources of Nutrient. Indian Journal of Pulses Research.16(1): 676.
Singh, R. K. and B. S. Yadav (2004). Effect of vermicopost and fertilizers on productivity of gram (Cicer arietinum) and soil fertility. Indian J. Agril. Sci., 74(11) : 613-615.

Panse, V. G. and P. V. Sukhatme (1967). Statistical methods for agricultural workers. ICAR publication, New Delhi.

Verma, R.K. 1976. Chemotherapeutic activity of five systemic fungicides in gram seedlings against three soil borne pathogens. M.Sc. Thesis, J.N. Agricultural University, Jabalpur, India.

\section{How to cite this article:}

Megha Dubey, V.K. Verma, Nidhi Verma, Anjum Ahmed and Usha Waskle. 2019. Effect of Seed Treatment with Fungicide, Micronutrients and Biofertilizers on Growth and Yield of Chickpea in Madhya Pradesh. Int.J.Curr.Microbiol.App.Sci. 8(11): 1045-1051.

doi: https://doi.org/10.20546/ijcmas.2019.811.123 